University of Wollongong

Research Online

Faculty of Social Sciences - Papers (Archive) Faculty of Arts, Social Sciences \& Humanities

2018

Strategies of policy advocacy organizations and their theoretical affinities:

Evidence from Q-methodology

Sheldon Gen

San Francisco State University

Amy Conley Wright

University of Wollongong, acwright@uow.edu.au

Follow this and additional works at: https://ro.uow.edu.au/sspapers

Part of the Education Commons, and the Social and Behavioral Sciences Commons

Research Online is the open access institutional repository for the University of Wollongong. For further information contact the UOW Library: research-pubs@uow.edu.au 


\title{
Strategies of policy advocacy organizations and their theoretical affinities: Evidence from Q-methodology
}

\author{
Abstract \\ Policy advocacy is an increasingly important function for many nonprofit organizations, yet their advocacy \\ activities have largely escaped theoretical grounding. The literature on nonprofits has described how they \\ engage in policy advocacy, without linking them to theories of policy change. The policy studies literature, \\ on the other hand, has explained how various forms of influence result in policy change, but has largely \\ ignored organizational perspectives on those processes. These two literatures remain largely \\ disconnected. Drawing upon interviews with a purposive sample of policy advocacy directors at 31 \\ nonprofit organizations, this study applies Q-methodology to identify and describe six distinct policy \\ advocacy strategies employed by the organizations, and their resonant theoretical views of policy \\ processes. These findings suggest strategic approaches for nonprofits seeking to influence policy \\ processes. They also enhance the academic literature on policy processes by adding the advocates' \\ views and expectations. Implications for further research are also identified.

\section{Keywords} \\ strategies, evidence, q, methodology, organizations, theoretical, advocacy, their, policy, affinities

\section{Disciplines} \\ Education | Social and Behavioral Sciences

\section{Publication Details} \\ Gen, S. \& Wright, A. C. (2018). Strategies of policy advocacy organizations and their theoretical affinities: \\ Evidence from Q-methodology. Policy Studies Journal, 46 (2), 298-326.
}




\section{Strategies of Policy Advocacy Organizations, and Their Theoretical Affinities: Evidence from Q-methodology}

\section{Introduction}

Since the 1960s, nonprofit organizations, particularly those established as interest and citizen groups arising from disaffection with government, have increasingly engaged public policy making processes to advance their causes (Berry, 1999; Berry \& Arons, 2005). However, our understanding of how nonprofit organizations do this generally remains separated in two distinct literatures. The literature on nonprofit organizations engaged in policy advocacy tends to focus on the organizations themselves, documenting what kinds of organizations engage policy processes and what enables them to do so (Casey, 2011; Child, \& Gronbjerg, 2007; Mellinger \& Kolomer, 2013; Mosley, 2010; Schmid, Bar, \& Nirel, 2008) as well as why they form and how they are maintained (Walker 1983). Often using survey methods, this research has examined nonprofits' roles in the policy process (Mosley, 2013), what tactics they employ (Mosley, 2011), and what makes them effective (Hoefer, 2000; Hoefer, 2005; Hoefer \& Ferguson, 2007; Leech, Baumgartner, Berry, Hojnacki, \& Kimbal, 2007).

Public policy theory and research, on the other hand, tend to focus on the processes of policy change, the situations that facilitate change, and the distribution of power among policy players. For example, collaboration among private and public actors in policy subsystems for strategic action is explored by policy network theory (Agranoff \& McGuire, 2003); the broader political context and how coordinated groups take advantage of opportunities and respond to constraints to advance their beliefs is the focus of the Advocacy Coalition Framework (Sabatier, 1988); and how power is distributed and negotiated by government officials and power brokers is 
variously considered by theories of pluralism (Dahl, 1967), group theories (e.g., Baumgartner \& Leech, 1998), elitism (Putnam, 1976), and iron triangles (Ripley \& Franklin, 1984). These theories and others in policy studies clearly have strategic implications for nonprofit organisations seeking to influence the policy process.

What is lacking is an understanding of how nonprofits view the processes of policy change, and to what extent they resonate with major policy theories. As Almong-Bar and Schmid (2013) note, "Strikingly, there are very few studies that have examined the advocacy activities of [nonprofit human service organizations] in relation to policy-making processes that use public policy-making theories or building on knowledge from policy studies” (p. 27). Examining how nonprofits attempt to affect policy change and connecting their activities and desired outcomes to policy studies theory is one way this divide can be bridged.

Policy advocacy strategies are comprehensive, long range approaches to policy change, while tactics are the specific advocacy activities employed within the strategies (Ganz, 2009; Berry, 1977). By examining the tactics nonprofit organizations combine into distinct policy advocacy strategies, we can link those strategies to policy theories that support their actions. In doing so, we can better understand how nonprofit organizations view the processes of policy change. The significance of this understanding is two-fold. For the policy advocacy organizations, it provides theoretical grounding for their strategies. Policy advocacy tends to be informed by wisdom literature and anecdotes, and little theoretical guidance or empirical evidence is available for strategic decision making. But articulated linkages between advocacy strategies and established policy theories can provide that guidance. For the policy studies community, it begins to bridge the gap between studies of advocacy organizations and theories of policy change, by identifying the policy processes in which those organizations engage. 
This paper uses Q-methodology to identify these strategies and to surface the subjective understanding of policy advocates about policy processes. Q-methodology is an established approach to systematically analyze patterns of subjectivity on topics of study. It combines semistructured interviews with a structured exercise that guides respondents to sort statements of opinion along a scale of agreement. It then uses factor analysis to identify underlying structures of viewpoints revealed from structured surveys.

\section{Tactics and strategies of policy advocacy}

Nonprofit organizations have developed a number of reports with logic models that suggest a variety of tactics for policy advocacy. Among them are those published by Action Aid (Chapman \& Wameyo, 2001), The Annie E. Casey Foundation (Reisman, Gienapp, \& Stachowiak, 2007), The Center for Community Health and Evaluation (n.d.), Grantmakers in Health (2005), Harvard Family Research Project (Coffman, 2007), and Innovation Network (Morariu et al., 2009). These logic models describe organizations’ approaches to the policy advocacy process using three main elements: inputs, activities, and outcomes. The types of activities and outcomes identified in these practitioner logic models are summarized in Table 1. While instructive, this literature has largely been based on practice wisdom, rather than informed by policy studies theory or empirical research on non-profit advocacy.

Studies that have surveyed nonprofit organizations on their policy advocacy have used various approaches to delineate a list of advocacy activities. Common categories are associated with the targets of advocacy, such as administrative advocacy, legislative advocacy, and media advocacy (Hopkins, 1992). Advocacy has also been characterized by the actions it entails, such as research and public education, coalition building and direct actions (Almog-Bar \& Schmid, 2013), developing consensus among experts, pursuing issues in court and aiding in the election 
of particular candidates (Hoefer, 2000, 2001). Walker (1991) took a broader view of advocacy approaches by looking at how organizations may use multiple activities as part of an overall "pathway to influence” (p. 103). He argued that activities tended to fall into two categories: an 'inside' strategy that seeks to build close ties with public officials and an 'outside' strategy that aims to influence and mobilize the general public. Following Walker, Mosley (2011) uses the classifications of insider and direct for those tactics that involved lobbying or engaging with the government through giving testimony or participating in commissions, while classifying as indirect those tactics that primarily focused on changing the climate around policy advocacy, such as coalitions or public education campaigns.

Few studies have explicitly linked advocacy outcomes with their intended outcomes. Schmid, Bar and Nirel (2008) used three categories of activities with implied outcomes in their study: 1) those intended to protect the rights of special populations, educate the public and achieve social goals; 2) those directed at influencing figures in the government or media; and 3) those attempting to gain access to decision makers in order to promote the organization's advocacy goals. Gen and Wright (2013) drew on practitioner literature and policy theory to hypothesize connections among policy advocacy activities that might lead to certain outcomes, with routes to policy change envisioned through influencing decision makers, indirect pressure on decision makers through public engagement, direct changes through litigation or pilots, shaping implementation of policy rather than its passage, and a strategy that focused on making the policy process more democratic and people-centered, rather than changing a specific policy. Explicitly connecting policy activities and outcomes with policy studies theory can lead to greater understanding of what tactics and strategies may be most successful for particular ends. Walker (1991) noted that interest group literature tends to be mostly case study driven, with 
different classification schemes and emphases that make generalization and theory-building difficult.

Linkages among the activities and outcomes described by practitioners are supported by a variety of policy studies theories that suggest certain activities or forms of influence may lead to particular types of outcomes. See Table 1 for theories that support connections among certain advocacy activities and the outcomes/impact to which they might lead. These theories are now described in brief, to lay out the potential linkages between policy advocacy activities and outcomes that are tested in this study.

\section{[INSERT TABLE 1 ABOUT HERE]}

\section{Theories linking policy activities and outcomes}

Theories on coalitions, issue networks, and interest groups suggest a link between building support among potential allies and the general population and changing public opinion to indirectly pressure decision makers for policy adoption. The advocacy coalition framework recognizes that organizations with shared interests can form coalitions that facilitate learning and collective action on policy issues (Sabatier, 1988). Resource mobilization theory suggests that advocates can gain patrons for their cause through use of tactics associated with public mobilization and the media: protests and social change activities can attract the interest and sympathies of potential adherents and media work can boost the visibility of such activities (McCarthy \& Zald, 2006). Interest group studies examine how organizational characteristics translate into their influence on policy (Baumgartner \& Leech, 1998), such as the ability to coordinate communication and engage and mobilize the public (Cahn, 1995). Olson's (1965) theory of latent groups cautions that the potential power of large groups is ineffective or latent unless individuals are induced to act. Taken together, this body of work suggests that 
coalition building can make groups and organizations more powerful in driving policy change collectively than they would be on their own, in part by demonstrating the level of interest in their issue to decision makers. Information campaigning among organizations and with the public can change policy preferences. Mobilizing and engaging the public in various ways like voting, protesting, or rallying demonstrates their will to decision makers. These influences on decision makers can ultimately spur their action to initiate policy change.

Institutionalism and elite theory suggest a path to policy change by directly influencing decision makers' views. Lobbyists with resources and political influence nevertheless face a major challenge in overcoming political bias toward the status quo, but when policy shifts it can do so dramatically and provide a major payoff for a sustained lobbying campaign (Baumgartner et al., 2009). Institutionalism views formal government players in the legislative, executive and judicial branches as well as government agencies as holding the power of policy change. Activities to build relationships with policy makers and lobby them on preferred policy directions evoke institutionalism (Cahn, 1995). Elite theory suggests that political power is actually held by a small segment of the upper social class with fairly uniform policy preferences that is aware and intentional about perpetuating its privileges (Mills, 1956; Putnam, 1976). Advocates can influence their views as an interim step to the elite exercising power over policy makers, though elite theory suggests that this group more often sways public opinion to follow their own (Edelman, 1964; Herman \& Chomsky, 2002).

The power of information and rhetorical framing to influence both the public and decision makers in setting the policy agenda and building political will for action is highlighted by rational decision-making, rhetoric studies and media studies. Rationalism is the underlying reason that advocacy organizations, particularly think tanks, produce research and analysis of 
policy issues to educate policy makers directly or influence them indirectly by informing the public (Lindblom \& Cohen, 1979; Weiss \& Bucuvalas, 1980). Empirical research has suggested a more limited role of research in policy influence, with the theories of incrementalism (Lindblom, 1959) and bounded rationality and satisficing (Simon, 1945) underscoring the suboptimal role of research in policy development and adoption. Presenting information in manner favorable to particular policy preferences, known as framing, is another tactic to influence the perspectives of decision makers or the public. This is often done through the use of anecdotes that highlight contexts, stakeholders and values related to policy issues (Nowlin, 2011). While an overarching theory is lacking, studies in the rhetoric literature have found that framing can be effective for gaining policy support (Schneider and Ingram, 1993). Using the mass media as a means of disseminating messages has also been found to be effective for building public awareness and support for advocates’ policy preferences (Nowlin, 2011), as well as propelling social issues on to a policy agenda (Iyengar \& Kinder, 1987), or raising the urgency of an issue for political action (Linsky, 1988). Engaging in public discourse and debate as a means of defensive actions to counter opponents' arguments is another strategy suggesting the importance of information and framing to influence decision makers, the general public, and organizations within policy subsystems. Defensive activities assume a pluralistic democracy in which policy influence is held by multiple competing factions (Dahl, 1967).

Attempting to influence policy through pilots, attention to implementation processes or litigation through the courts are less orthodox strategies that nonetheless have support in policy studies theories and scholarship. Incrementalism (Lindblom, 1959) recognizes that policy is often made through low-risk, low-impact decisions that gradually shift a policy direction rather than comprehensive rational decision making. Advocates can make strategic use of 
incrementalism by demonstrating efficacy of a potential policy approach through small-scale pilots when comprehensive reform is politically infeasible. Advocacy focused on implementation rather than policy passage has an implicit bottom-up view that bureaucrats have significant discretion to interpret and apply policies (Hill \& Hupe, 2011). This stage of the policy process can also provide an opportunity to evaluate whether adopted policies are achieving their goals (Nachimas, 1980). Monitoring policy implementation offers advocates an opportunity to influence the policy agenda: either to keep an issue off the policy agenda and maintain the status quo or put an issue back on the policy agenda to enable reform. Advocates may use litigation as a strategy when they perceive that they do not have influence with the executive or legislative branch. The theory of adversarial legalism (Kagan, 1991; Kagan, 1999) identifies the formal legal contestation as a process for invoking legal rights, duties and procedural requirements related to policy. This advocacy strategy can fit organizations with resources such as staff attorneys, emphases such as discrimination or good governance, and goals to challenge ideological opponents and earn media coverage of their issue (Epstein, Kobylka \& Stewart, 1995). Kagan (1991) cautions that adversarial legalism has drawbacks as well as benefits: while the courts can enable the politically weak to demand their rights from the government, as in the case of the civil rights movement, the unpredictable and costly nature of litigation makes this a potentially risky strategy. Group mobilization of the law, when people or organizations come together to form class action lawsuits, can spread risk and work together with other strategies, such as when a group of organizations form a coalition to file an amicus brief with the courts (Wasby, 1983).

Moving backward from policy outcomes to the activities that may impact upon them, multiple streams theory and studies on public participation suggest activities for advocates 
interested in influencing the policy agenda or promoting a more democratic policy making environment. Kingdon's (1984) multiple streams theory notes that policy change can happen when three streams of activity converge: a problem stream with information about a social problem, a policy stream about how to address the social problem, and a political stream in which the political climate or public mood favors action on the social problem. Each of these streams have implications for potential advocacy activities to influence the policy agenda: information campaigning to build awareness of the problem in the problem stream, research to support potential policy directions in the policy stream, and lobbying decision makers to build political will and/or engaging the public through information campaigning and mobilization in the political stream. Studies of public participation in the policy making process suggest that engaging the public can also contribute to broader outcomes about policy making in a democratic environment, including legitimizing the policy process by enabling broader public input and earning great public support (Bryson \& Anderson, 2000; Smith \& Huntsman, 1997; Xu, 2001) as well as producing more effective policy (Kastens \& Newig, 2008) with better distribution of benefits to stakeholders (Gallagher \& Jackson, 2008).

Taken together, these theoretical linkages between policy advocates’ activities and expected outcomes provide a menu of hypothesized tactics to empirically examine. This paper seeks to identify patterns of shared understandings among nonprofit organizations about groupings of tactics that constitute overarching advocacy strategies, and how those strategies are supported by policy theories. Specifically, it addresses the research question: What are distinct strategies employed by policy advocacy organizations? The answers to this question reveal these organizations' viewpoints on policy making processes and how they overlap with policy theories. 


\section{Methods}

To address this research question, Q-methodology was employed with interviews of 31 individuals who manage their respective organizations’ policy advocacy efforts. Q-methodology is a “...systematic and rigorously quantitative means for examining human subjectivity” (McKeown \& Thomas, 1988, p. 7). ${ }^{1}$ It employs factor analysis to identify underlying structures of viewpoints collected from structured surveys. However, its application of factor analysis is opposite that typically found in survey research. In the typical R-method that is dominant in social sciences, the variables being analyzed are statements in a survey, while the cases are the respondents. $^{2}$ The resulting factors are clusters of statements that reveal underlying meanings among them. In contrast, factor analysis in Q-methodology treats the statements as the cases and

${ }^{1}$ Q-methodology’s development is credited to British psychologist and physicist William Stevenson in the mid-1930s (Brown, Durning, \& Selden, 1999; Watts \& Stenner, 2012). Since then, it has been widely applied to varied fields including human development, medicine, healthcare, policy analysis, education, social work, journalism, and communications. In its first fifty years, over 1,500 publications employed the method and a journal dedicated to the method was established (McKeown \& Thomas, 1988, p. 11). Operant Subjectivity: The International Journal of Q Methodology is now in its $38^{\text {th }}$ volume. Even so, McKeown and Thomas characterized Q-methodology in 1988 as holding “fugitive status” within social sciences (p. 11), and Watts and Stenner described it in 2012 as “underused” (p. 18). For this reason, we provide an extended description of the method and its application to this study.

2 Watts and Stenner (2012) credit William Stevenson with labelling the foundational factor analysis method as "R-methodology", a reference to the correlation coefficient it is based upon. 
the respondents as variables. Respondents rank the relative importance of the statements based on their internal point of view, and the resulting factors are clusters of respondents with related viewpoints on the phenomenon represented by the statements. Watts and Stenner (2012) succinctly label Q-methodology a “by-person” factor analysis, in contrast to the more common “by-variable” (or by-statement) factor analysis of R-methodology (pp. 10-13).

Because Q-methodology identifies underlying viewpoints of its subjects, Brown (1980) concluded that it is “...pertinent to the study of public opinion and attitudes, groups, roles... [and] virtually all areas of concern to the social and political sciences” (p. 58). Applied to this study, the statements are opinions of advocacy activities and their resulting outcomes, and respondents sorted them by their relative importance to their organizations. The resulting factors identify unique viewpoints of nonprofit organizations on the processes of policy change and how they seek to influence those processes. Our interpretation of these factors compare them to existing theories in policy studies.

Practitioners’ professional discussions on policy advocacy, or their “concourse” in the language of Q-methodology (Stenner \& Watts, 2012, p. 34), are most formally represented by the logic models of policy change that have been published by them (Chapman \& Wameyo, 2001; Reisman, Gienapp, \& Stachowiak, 2007; the Center for Community Health and Evaluation, n.d.; Grantmakers in Health, 2005; Coffman, 2007; and Morariu et al., 2009). While these logic models identify the major categories of advocacy activities and outcomes, reflected in Table 1, most are not specific about the linkages between individual activities and outcomes. However, as discussed in the previous section, the policy studies literature suggests certain connections. Drawing on these theoretical linkages between activities and outcomes, 24 statements about policy advocacy tactics were developed, constituting this study's Q-sample. 
(Table 4, in the next section, lists these statements.) These are individual statements of opinion on policy advocacy linkages, which respondents sorted onto a bell-shaped distribution ranging from -3 (least agree with organization's approach to policy advocacy) to +3 (most agree with organization's approach to advocacy). By analyzing how respondents sorted these statements of opinion on policy advocacy, distinct viewpoints on policy advocacy strategies were identified.

The sample of nonprofits recruited for this study were systematically and purposively selected. First, Guidestar was used to identify the population of nonprofits in San Francisco, Sacramento, and Washington $\mathrm{DC}^{3}$, that self-identified themselves in their IRS filings with NTEE prefix code R (advocacy) or suffix code 01 (advocacy in a specific prefix area) ${ }^{4}$. Of course, these filters would exclude many organizations that engage in policy advocacy, but they would certainly capture those that engage in advocacy as a primary activity, and would therefore be expected to provide well-articulated approaches to policy advocacy in the interviews. Still, these

\footnotetext{
${ }^{3}$ The national capital, a state capital, and a major city were deliberately selected to capture organizations advocating at different levels of government. It was discovered, however, that organizations' locations did not reliably predict the levels of government in which they advocated, so the final sample focused primarily on San Francisco organizations for logistical reasons, while ensuring that all levels of government were represented by the respondents. Still, a few organizations from Sacramento and Washington DC were included.

${ }^{4}$ The National Taxonomy of Exempt Entities (NTEE) is a classification system for nonprofit organizations developed by the National Center for Charitable Statistics and used by the IRS. Nonprofits filing their revenues with the IRS self-identify their primary classification from a list of over 600 codes. Of these codes, 45 are related to advocacy. For a full explanation, see nccs.urban.org/classification/ntee.cfm.
} 
NTEE codes do not distinguish between case advocates and cause advocates. Case advocates represent and assist clients to access resources and services, with the aim of improving the clients’ welfare. Cause advocates, on the other hand, represent groups and their interests to affect policy processes and social systems and conditions (Kirst-Ashman \& Hull, 2008). While it is not unusual for an organization to do both kinds of advocacy, this study is interested in the latter because they more likely engage in policy advocacy. Therefore, as a final screen for the sample, Internet searches of the organizations were conducted to decipher whether they engage in policy advocacy, and if so, the levels of government they engage. From the resulting set, we purposively sampled organizations to capture wide variance among major issue areas (selfidentified from their NTEE codes), levels of government, and reported expenditures.

We hypothesized at least five distinct advocacy strategies, based upon an earlier analysis of advocacy organizations’ logic models for policy advocacy (Gen \& Wright, 2013), so we targeted at least 20 organizations for our sample, to meet the recommended minimum for extracting five factors in Q-methodology (Watts \& Stenner, 2012, p. 197). Table 2 summarizes key characteristics of the final 31 participating organizations. While 31 respondents would be inadequate in R-methodology's application of factor analysis, it is ample for Q-methodology. Five or six respondents significantly loading onto each factor usually produces "highly reliable factor scores” (Brown, 1980, p. 67) that identify generalizable viewpoints.

\section{[INSERT TABLE 2 ABOUT HERE]}

For each organization, we identified the staff member who managed the organization's policy advocacy efforts. For smaller organizations, this was often the executive director. In larger organizations, it was often a policy director. A member of the research team met with each respondent, and conducted a semi-structured interview followed by the Q-sort exercise. 
Each interview covered the organization’s policy issues; its advocacy resources, activities, and outcomes; and a case of policy advocacy that represents the organization's approach. The researcher then facilitated the Q-sort, asking the respondent to review the 24 statements, thenin a sequence of structured steps_-sort them onto the rating scale.

The resulting Q-sort data were analyzed using PQMethod software, applying centroid factor analysis with varimax rotation, to identify distinct viewpoints on policy advocacy, and to identify the organizations that most significantly associate with each viewpoint. The resulting factors were each interpreted following the process prescribed by Watts and Stenner (2012, p. 147-167) that converges both the statistical and interview data. The factors identified the organizations with common viewpoints, and those organizations’ interview data pertaining to their advocacy activities and outcomes were incorporated to better understand the quantitative results.

\section{Findings}

The factor analysis was conducted four times, to extract four, five, six, and seven factors from the data. These extractions were compared by the cumulative variances they explained, the numbers of different organizations loading onto each factor, the numbers of confounding sorts (i.e., organizations that load onto more than one factor), and the numbers of non-significant sorts (i.e., organizations that do not load onto any factor). The six-factor extraction was the most efficient in that it loaded the most organizations onto the fewest factors. It explained $61 \%$ of the variance in the data while loading at least five organizations onto each factor, and accounting for all but one organization, at the 95\% level of confidence. Table 3 summarizes the organizations significantly loading onto each of the six factors. Note that a few of the significant loadings are negative, meaning that the organizations are negatively related to those factors. In practical 
terms, this means the organizations significantly disagree with the strategies represented by those factors. Positive loadings, on the other hand, mean the organizations are positively related the factor and significantly agree with the strategies represented by those factors. These loadings can be interpreted like correlation coefficients, in that the closer the loading is to 1.0000 , the stronger the relationship between the organization's strategy and the factor. A careful examination of Table 3 reveals that few loadings are greater than 0.7 , and only one reaches 0.8 . Thus, no organization's strategy is perfectly represented by any of the factors. Instead, an organization's strategy might overlap with a factor or two. That is, the factors represent commonalities in the strategies among the organizations, but each organization might employ more than one strategy in their advocacy campaigns. For these reasons, the interview data were reviewed to find the parts of each organization's strategies that overlap with its factor, in order to describe and explain the factor.

\section{[INSERT TABLE 3 ABOUT HERE]}

\section{[INSERT TABLE 4 ABOUT HERE]}

Table 4 summarizes the resulting Q-sort arrays for the six factors. Each array reports how the 24 Q-sample statements are sorted in the factor, on the same scale of -3 to +3 . Interpretation of these arrays were guided by the “crib sheet” procedure prescribed by Watts and Stenner (2012). This process systematically focuses attention on not only the lowest and highest rated statements in each array, but also those statements with ratings that are lower or higher in one factor than in any other, no matter the absolute value of the rating. Doing so highlights the relative differences between the factors.

The rest of this section presents the interpretations of these six factor arrays and the policy advocacy strategies they represent, in order of the factors’ eigenvalues, from largest to 
smallest. ${ }^{5}$ Each interpretation begins with a summary of its key statistics, followed by a description of the advocacy strategy based upon the statement ratings in the array. In these descriptions, statement numbers and their ratings are referenced parenthetically (e.g., 11:+2 means statement 11 has a rating of +2 in the factor array). Schematic pathways ( $a$ through $h$ ) are also included in these descriptions, to graphically summarize the causal relationships assumed in each factor. Finally, interview data are reported to further describe and explain each strategy/factor.

\section{$\underline{\text { Public lobbying strategy (Factor 1) }}$}

The public lobbying strategy had an eigenvalue of 7.12 and explained $11 \%$ of the variance in the Q-sorts. Four of the 31 participating organizations were significantly associated with this strategy at the 99\% confidence level, and an addition three were significantly associated at the $95 \%$ confidence level.

Nonprofits employing this strategy view themselves as champions of public interest issues and engage the policy process in order to affect broad improvements in physical and social conditions $(08:+3)$ and to make the policy process more responsive to public interests $(11:+2$, 12:0, 24:+2). They accomplish these goals by lobbying policy makers $(02:+3)$-which may be legislators or government administrators - as they see these policy makers as the key to policy change (22:+2). Their approach is less confrontational than others (03:-2, 05:-2, 17:-3), preferring the development of long-term relationships with policy makers. Also, although they charge themselves to promote public interests, those interests are generally determined by

\footnotetext{
${ }^{5}$ An eigenvalue is the sum of squared factor loadings, a measure of the variance explained by the factor. The eigenvalue of 1.00 is generally accepted as the threshold above which factors are deemed reliable and worthy of interpretation, because the factor would explain more variance than a single Q-sort would on its own (Watts \& Stenner, 2005). In this study, each factor had at least five Q-sorts loading significantly.
} 
themselves, not through direct community engagement (14:-2). Indeed, influencing the public's views is not a part of the strategy (09:-1, 18:-3).

(a) Policy advocacy $\rightarrow$ democracy, people-centered policies, effective policies

(b) Lobbying $\rightarrow$ policy makers' views $\rightarrow$ policy change $\rightarrow$ social/physical conditions

The seven organizations in this study that were significantly related to this strategy advocate in a broad range of policy issues, including child welfare, juvenile justice, power supply, open lands, and performing arts. Their commonality is their view that the public in general benefits from favorable policy changes in these areas, even though the public is not well informed or mobilized in these areas. So their jobs are to advocate on behalf of the public's interests. As one executive director explained, “Consumers can't tell on their own what's good” in policies on power supply, so instead, "The grassroots depend on us to have expertise on the policy.” His organization “...fights against regulation in the corporate interest, and fights for regulations in the public interest. That is the framework that guides our work.” Another director working in land conservation described her organization as a trustee of national land, working to keep the land accessible for public use and enjoyment. Still another explained that his organization works “...on behalf of our conviction that the performing arts are an essential public good, critical to a healthy and truly democratic society.” In all these examples, the advocates have a strong sense of responsibility to act on behalf of the public's interest, even if not directly engaging the public.

These advocates’ approach to lobbying are generally collegial, rather than adversarial. Key to their efforts are building "one-on-one” relationships with policy makers, and providing them with credible research and information. One policy director described her job as a "teacher" of legislators on her area of expertise, so she works hard to build and maintain the 
rapport in those relationships. Another described with pride her organization's reputation and relationships with city staff and council members, and how these relationships allow her to advocate for children's programming. A third policy director explained clearly the rationale behind these collegial relations when he said, "We [advocates] have a tradition of going up to the building and screaming, but we need a different approach if we want to get inside the building and have a meeting... You have to translate the urgency that makes you want to be loud and scream, and translate this into persistence and diplomacy.”

One variation of this strategy that was popular among the seven related organizations is the use of existing public support to complement the lobbying efforts. This is subtly different than other strategies' use of public pressure to sway policy makers’ decisions. Instead, public mobilization in this strategy is to provide decision makers with cover for their existing stances. The advocate for open lands described this as an “insider's game” in which he provided legislators not only with technical research to justify a policy, but also the public support to make the policy politically helpful for the legislators. Another variation is the target of the lobbying. While much of the lobbying targets legislators, this strategy is also applied to administrative processes. An advocacy organization in juvenile justice issues directs much of its efforts on the juvenile detention facilities, and how they implement policy. Another focused on the regulatory body overseeing power supply, to change administrative procedures rather than legislative statutes.

Inside/outside strategy (Factor 2)

This inside/outside strategy had an eigenvalue of 3.12 and explained $12 \%$ of the variance in the Q-sorts. Six of the 31 participating organizations were significantly associated with this 
strategy at the 99\% confidence level, and an addition one was significantly associated at the 95\% confidence level.

This strategy is distinguished by its two-prong approach to advocacy. In the primary one, organizations indirectly influence decision makers by applying public pressure through information campaigns and media work $(01:+3,06:+3+, 05:+1)$. This constitutes the "outside" component of the strategy. In the other prong, organizations nurture relationships with one or a few influential issue champions from within the decision making body such as the legislature or an executive office (02:+2), helping those insiders sway their peers with information and shows of public support $(10:+2)$. Together, these two tactics lead to their ultimate objective, which is favorable policy change $(16:+2)$ :

(c) (Information campaigns, media work, rebuttals) + (lobbying, coalitions) $\rightarrow$ policy makers' views $\rightarrow$ policy change

While the strategy does employ pressure from the public, it is pragmatic in that its objectives are clearly focused on specific policy outcomes, rather than broader ideals of democracy (11:-3, 12:2, 21:-2). Indeed, the political view of this strategy recognizes the power in legislative and administrative processes and chooses to work within that power structure rather than to bypass it through direct reforms (17:-3, 13:-2). For example, a children’s advocacy organization sought a major reform in a state's financing of public schools. They had long developed the proposed reform, and had positioned themselves as the primary "outside” advocate in the issue. In that role, they gathered and analyzed data, synthesized relevant research, and developed and disseminated arguments for their proposed policy change. As its executive director described, they became "ground zero on all information and communications" on the issue. When the state elected a new governor sympathetic to their cause, they targeted the governor as their inside 
champion and lobbied for his support. "Successful campaigns need lots of folks," explained the executive director, "but you need a champion on the inside and outside." With the election of the new governor, the advocacy organization saw an opportunity for the "policy window" (the executive director's own words) to open for this issue if they could secure the governor's efforts.

While the outside champion in the above example was the policy advocacy organization itself, sometimes the advocates will organize a broader outside champion, such as the public or a coalition of groups. In one case an advocacy organization fought for stricter standards on car emissions, which would encourage the further development of alternative fuels. Their effort was heavily opposed and outspent by representatives of major oil companies. Rather than standing alone to face that opposition, the advocacy organization built a coalition of organizations and garnered broad public support through their research and media work. The policy director explained that it can be helpful to have a "big bad opponent” that lacks a positive public image. It makes it easier to "generate a lot more public interest and support."

The inside champion, however, is usually a specific individual or small group of individuals within the decision making body. The strategy is deliberate in focusing on a few inside individuals to sway their peers, rather than directly lobbying the entire decision making body. It assumes that the inside champions have a better understanding of the competing interests of their peers, so they are in a better position than the advocacy organization to negotiate for support. As one advocacy director put it, they don't broadly lobby the legislature because "we want to get things done!” Their efforts in lobbying would be futile compared to those of an inside champion.

Key to this strategy is the information campaign that is often used to mobilize public support and apply pressure on decision makers. Many of these organizations have in-house 
researchers who collect and synthesize information on their issues, and some have staff trained in media and public relations. The research can be original or others', but in this strategy the policy preferences must be substantiated by empirical evidence in order to garner support from the public and editorial boards, and provide support to the inside champion. To translate such evidence to the public, these policy advocates develop messages and frame the issues in ways with broad appeal. One policy director said her job is to "dewonkify" complex problems and solutions to messages that anyone can understand. In her case, her organization sought the adoption of a 15 mph speed limit around all schools in her city. While the issue had conflicting perspectives from law enforcement, traffic engineers, neighbors, parents, and drivers, she recognized that everyone could sympathize with the perspective of the pedestrian student, so she framed the issue from that perspective and used the media to build support for the proposal.

\section{Direct reform strategy (Factor 3)}

The direct reform strategy had an eigenvalue of 2.95 and explained $11 \%$ of the variance in Q-sorts. Three of the 31 cases were significantly associated with this strategy at the 99\% confidence level, and another four were associated at the 95\% confidence level.

In this strategy advocates bypass legislative processes to directly influence policy change through judicial $(17:+3)$ or administrative $(07:+1)$ processes. They supplement these efforts with information campaigns aimed at building general awareness and support for their causes (06:+2, 16:+2, 20:+2). Even so, their aim is not a more democratic or responsive system (12:-3, 18:-2, 21:-2), nor is it to mobilize the public or create coalitions around their causes (10:-2, 14:-3). Instead, this strategy focuses on specific policy changes to improve social or physical conditions of their represented interests (08:+3). 
(d) (litigation, monitoring) + information campaign $\rightarrow$ policy change $\rightarrow$ social/physical conditions

Oftentimes, advocates using this strategy are litigants using the judicial system to seek policy relief for those they represent. One advocate called this “impact litigation,” the pursuit of policy change through the court system for large numbers of people, such as through class action lawsuits. Of course, this approach to direct reform requires specialized training in the legal system. The sizes and the sophistication of these organizations vary widely in our data, but the basic components of this strategy are common among them. For example, on one extreme, a one-person nonprofit organization — who is an attorney—sought a ban on a specific ingredient popular in processed and prepared foods. He sued a major food processor, and later a major fastfood chain, for their use of the ingredient, claiming adverse health effects, even death, for those consuming their food. Within days of filing his suit, he earned local media coverage by a newspaper, and within a few weeks he was on major national media outlets. The intense public attention on the issue was enough for the food processor to propose to settle the case out of court. They offered to remove the ingredient from their products, in exchange for dropping the case without prejudice. The US Food and Drug Administration also responded to the public scrutiny by proposing and eventually adopting regulations requiring the labelling of the ingredient in all food products.

On the other extreme, another case was championed by an established nonprofit organization with 24 employees, including attorneys, researchers, and public relations staff. This organization is engaged in ongoing efforts to tighten regulations on, and eventually close down, coal-fired power plants in the U.S. They represent plaintiffs in lawsuits against specific power plants across the U.S. In a typical suit, they challenge the government permits issued to the 
plant, demanding further restrictions on emissions. Research they compile or produce are key parts of these suits. Local public awareness is also, so they build local coalitions to drum up support for their suits. To them, the research and public awareness is part of the strategy, to put public pressure on the defendants. As the founder of the nonprofit explained, "Litigation, policy analysis, and media outreach" are the key activities of their advocacy campaigns. They work together to place pressure on the judicial process for policy change.

Other advocates using this strategy engage administrative processes or direct community work, rather than judicial systems, to get changes in the implementation of policies. One advocacy organization, for example, partnered with juvenile detention facilities to develop data collection and analysis systems for their facilities. The analyses, in turn, are used to improve practices in the facilities to better serve the public and the detainees. Another advocacy organization is a foundation that funds projects to maintain or advance voter accessibility. The projects they fund employ many methods of direct reform, including litigation and education, but in all cases they seek to directly impact voter accessibility, rather than indirectly through legislative processes. Their advocacy director explained that they certainly welcome changes to public policy resulting from their actions, but they are more focused on implementation reforms than policy solutions.

\section{Popular power strategy. (Factor 4)}

The popular power strategy had an eigenvalue of 2.23 and explained $10 \%$ of the variance in the Q-sorts. Four of the 31 participating organizations were significantly associated with this strategy at the 99\% confidence level, and an additional one was significantly associated at the 95\% confidence level. 
Like the public lobbying strategy, the popular power strategy is also aimed at advancing the public's interests and democratic policy making. However, its approach is completely different. While the public lobbying strategy focuses its activities on formal policy makers, the popular power strategy eschews them (15:-3, 05:-2). Instead, organizations adopting the popular power strategy aim to sway the public's views in order to change policies $(14:+1)$ and social conditions (08:+2), and to build more responsive and democratic systems of policy making $(21:+2)$. They use a variety of methods to influence the public's views, including coalition building (04:+3), public mobilizations (14:+2), media and information campaigns (09:+3), framing and messaging (20:+2), and rebutting opposing views (18:0).

(e) Coalitions, media work, rebuttals/debate $\rightarrow$ public views $\rightarrow$ policy agenda, change $\rightarrow$ social/physical conditions

(f) Coalitions, media work, rebuttals/debate $\rightarrow$ responsive policies/democracy However, they generally do not engage in research and analysis (23:-3), policy monitoring and evaluation (07:-2), or demonstration projects (13:-2), which tend to target narrower audiences. Instead, their preferred tactics revolve around affecting broad public demand, rather than direct action, in order to initiate policy changes and more responsive policy making systems (14:+1, 21:+2).

For example, one participating organization facilitated a broad campaign on immigration policy reforms. Their executive director explicitly discounted policy change as their direct goal. "Others do that," she said. Instead, their measures of progress are the numbers of people and groups who are advancing the issue. By building these coalitions, they expect policy to follow. “We bring attention to issues... Instead of our audience being policy makers specifically, it’s more all the people doing this work, and we say [to them] you should be thinking about this issue 
and this angle. Getting people to think in different ways, that is how we influence the debate.” She called this kind of work the "infrastructure-building side of advocacy," focusing more directly on participation than policy outcome.

How these advocates engage the public in their issues vary widely. The above organization identified key stakeholders and convened meetings of them. Two other organizations created opportunities for the public to gain personal experiences with the issue. In one case, an organization sought to "democratize" local education policy and administration by empowering parents to advocate at school districts and school sites. They trained parents in school governance structures and processes, then encouraged them to engage their local schools to meet their demands for their children's education. Of course, these parents already had stakes in the issues (their children), but the organization empowered them to be policy advocates for their children within the district and site. In another case, the public's stake in the issue had to be taught by the advocacy organization. An environmental group working to raise environmental standards of coal-fired power plants needed to convey to the public how such plants affect them personally, even if they are far away. So, in earned media coverage, they invited the public to send samples of their hair to a laboratory that would measure the amounts of mercury found in them. (Mercury is a pollutant resulting from coal-fired power generation.) By revealing the personal stakes in the issue, the organization gained broad public support for their cause. This advocacy organization selected this strategy because it utilizes their competitive advantage in the policy debate: public support. "The way you influence public policy is you basically have the power of money and you have the power of people," explained the policy director. "We are never going to match [the opposition's] money, so we invest heavily on the people side... We 
have a grassroots army—boots on the ground — 2.3 million members and supporters that are joining [us] and committed to working on policy change.”

Another method used in these cases to garner public attention and support is through protests and what one respondent called "theatric events." One advocacy group sought an end to the United States' wars in Iraq and Afghanistan, and while they saw their efforts as part of a larger one to change policy on these wars, their direct involvement was much more limited. Their objective was simply to draw people's attention to alternative views of the wars. They did so through "in-your-face theatric events," ones that would earn media and public attention. Indeed the organization's director of advocacy was trained in theater and she used that background to communicate in dramatic forms their organization's alternative views. Institutional partnership strategy. (Factor 5)

The institutional partnership strategy had an eigenvalue of 1.84 and explained 9\% of the variance in the Q-sorts. Three of the 31 participating organizations were significantly associated with this strategy at the $99 \%$ confidence level, and an additional three were significantly associated at the $95 \%$ confidence level.

Advocacy organizations employing this strategy view government institutions as central to policy making, and they pursue policy changes by collaborating with them $(02:+2)$. The advocates provide policy makers with organized public support (10:+3), research $(15:+3)$, messaging (01:+2), and sometimes pilot programs $(13:+2)$ to catalyze the policy makers' support. These advocates see themselves as partners with the government institutions, not adversaries of them. Indeed, they generally avoid public debates (05:-3, 18:-3), litigation, (17:-2) and other confrontational tactics that might deteriorate their relationships with the policy makers. They also avoid indirect tactics such as media work (06:0) that they don't completely control. 
Because these advocates work primarily with decision makers directly, they view their purpose more narrowly focused on specific policy changes, and not more broadly on social changes (08:2) or democratic enhancement (11:-2).

(g) Coalitions, research, messaging, lobbying $\rightarrow$ policy makers' views $\rightarrow$ policy change A policy director of one of the significantly associated advocacy organizations succinctly summarized this strategy's view of policy change when she said, "There are three places to address [policy] issues: legislators, administration, and the courts. [We] are involved with all three.” The statement not only identifies the centrality of government institutions in policy change, but also the breadth of government institutions this strategy targets. This particular organization's advocacy efforts focused on issues of criminal justice, and indeed their key advocacy activities included producing and summarizing research written for legislators, agency administrators, and the courts through amicus curiae briefs.

Another organization focuses on a state’s foster care system, and their primary advocacy tactic builds relationships and understanding between legislators and the organization's constituents. They sponsor a shadowing day, in which legislators follow foster youth through their experiences in the foster care system. They also organize a lobbying day, in which foster youth meet with every member of the legislature plus the governor and lieutenant governor to share their proposals for reforms in the foster care system. Together, these activities help legislators understand how the existing foster care system works and how it could be improved. The organization's policy director explained that some legislators had no prior understanding of foster care, relaying how one legislator once asked a foster youth, "What did you do to get yourself into foster care?” The organization recognizes that many policy makers simply are not aware of these issues, so educating them in constructive ways, rather than confronting them with 
adversarial tactics, builds collaborative relationships that can result in policy changes. In this case, their efforts led to the passage of a recent significant reform to the foster care system despite concerns of its fiscal impacts on the state budget.

\section{$\underline{\text { Indirect pressure strategy. (Factor 6) }}$}

The indirect pressure strategy had an eigenvalue of 1.52 and explained $8 \%$ of the variance in the Q-sorts. Three of the 31 participating organizations were significantly associated with this strategy at the $99 \%$ confidence level. Two additional organizations were significantly associated at the $95 \%$ confidence level.

Advocates using this strategy affect policy change by influencing policy makers, but they do so indirectly rather than through lobbying or other direct tactics. They choose to convey public opinion (19:+3), use the media (06:+2), and implement pilot programs (13:+2) to apply pressure on the policy makers. These advocates believe that with these pressures, policy makers will affect their desired policy changes $(22:+2)$ to improve social and physical conditions $(08:+3)$.

(h) Public's views, media, pilot programs $\rightarrow$ policy makers'views $\rightarrow$ policy change $\rightarrow$ social/physical conditions

While these advocates will use public opinion to sway decision makers, they do not directly engage in swaying the public's opinion (18:-2). They simply mobilize the public that is in support of their efforts. Therefore, their aim is focused on specific policies and social changes, and not generally on reforms of the policy making processes (12:-3, 24:-3, 11:-2).

One organization associated with this strategy advocates for urban open spaces. Their policy director explained their rationale for focusing on the public rather than policy makers, saying that elected leadership changes frequently while the public's stakeholders in the issues do 
not. So they choose to mobilize the public to be advocates of the issue no matter who is in public office. "Real people... speak louder" than legislators, she explained. So they

“...empower, organize people so they know each other, they know their neighborhood,” and can effectively advocate for open spaces. Key to their effort in empowering neighborhood advocates is equipping them with data and information to support their preferences and arguments. "We drive our movements with data,” she explained. “Our advocacy is about lining up... academic and data rigor with community relationships, and reinforcing what people feel with actual data.” The data “...empower neighborhoods with real tools that speak louder to the [county] supervisors when real people are speaking up and sharing [how] they are personally affected.”

\section{Discussion}

The objective of this study was to empirically identify distinct and coherent policy advocacy strategies employed by nonprofit organizations, and interpret their corresponding viewpoints on the processes of policy change, something that the professional and academic literatures have largely ignored. The former tends to describe long menus of advocacy activities and objectives without linkages to guide their selections by organizations. The latter has focused on specific tactics (e.g., media work, lobbying, coalitions) without considering the larger strategies in which they are employed, or the processes of policy change without considering the individual advocates in those processes. This study begins to fill this critical gap by using Qmethodology to comprehensively reveal six approaches to policy advocacy found among policy advocacy nonprofits. These strategies provide nonprofits some degree of guidance in policy advocacy by describing the viewpoints, activities, and goals of each. It also allows us to lay a theoretical foundation under advocates’ existing practices. Table 5 begins this work by summarizing the viewpoints and tactics of these distinct advocacy strategies, and identifying key 
policy theories with which they appear to be aligned. It is important to emphasize that the strategies' affinities to theories are our extrapolations of those theories onto the strategies we've identified among our data. Most of the cited theories were developed outside this study's context of nonprofit organizations. Still, our extrapolations are based upon the strategies' and theories' common views of the processes of policy change, the distribution of power in those processes, and decision making processes in policy change.

\section{[INSERT TABLE 5 ABOUT HERE]}

The distinguishing tenets of the public lobbying strategy are its focus on direct interaction with formal policy makers (e.g., legislators, administrators), and lobbying as its primary mode of interaction. Advocates adopting this strategy see policy making power concentrated in autonomous government players, reflecting an institutional view in which policies are outputs of formal-legal processes (Cahn, 1995; Selznick 1996). And while this view can support a variety of advocate tactics engaging policy makers, this strategy prefers lobbying through the development of congenial relationships. This tactic aligns strongly with Walker's (1991) inside strategy and Baumgartner et al.’s (2009) study of lobbying.

The inside/outside strategy views two separate necessary conditions for policy change: and champion on the inside of the policy making body, and demonstrated outside public support to apply pressure for change. While Walker (1991) generally described advocacy organizations as adopting either inside or outside strategies, we observed organizations adopting both into this coherent and influential approach. The inside component here, however, is not as general as Walker's. For his inside strategy, Walker described broad-based lobbying of “political and administrative leaders” usually applying leverages including financial resources, substantive expertise, and constituency pressure. In the inside/outside strategy, however, we observed 
focused lobbying and recruitment of an identified political partner, such as a legislator or executive. Overall, the strategy echoes key aspects of Kingdon's (1984) streams theory in that the window of opportunity for policy change opens with the confluence of multiple factors. In the problem and policy streams, advocacy organizations articulate the social problems needing policy intervention and develop proposed solutions to them, providing the evidence and arguments supporting them. In the politics stream, the advocates develop political will among decision makers by demonstrating strong public support and pressuring decision makers to act. Lastly, advocates identify and support a policy entrepreneur on the inside of the legislature or executive branch, who can usher the issue through the decision making process. While Kingdon's streams identify the conditions necessary for policy change, the inside/outside strategy identifies assignments to key players inside and outside the decision making process to facilitate policy change.

The direct reform strategy includes tactics that use judicial or administrative processes, in lieu of legislative processes, to affect specific reforms in policies or administrative practices. In the judicial tactic, advocates in our dataset were plaintiffs or legal counsel to plaintiffs in lawsuits or threats of lawsuits. Their policy preferences are thus directly advanced through adversarial legalism (Kagan, 1991, 1999) rather than the more congenial tactics of inside strategies. In the administrative tactic, advocates demonstrate successful reforms on small scales to agencies and the public, with the aim of inducing broad-based reform. In effect, these advocates lower the risk of systemic change by demonstrating success on a smaller scale first. Their tactic adapts incremental decision making to break-down systemic change into a sequence of lower-risk decisions. While Lindblom (1959) formulated incrementalism as a descriptive theory of sub-optimal decision making, advocates take advantage of incrementalism's low-risk 
outcomes to promote their proposed changes. In both tactics, advocates also use the media to raise public awareness of their issue and increase political pressure for policy change (Linsky, 1988).

The popular power strategy embodies the stereotypical grassroots approach to policy advocacy, and aligns with Walker's outside strategy (1991) and resource mobilization theory (McCarthy \& Zald, 2006). It views legislatures and other government offices not as autonomous decision makers, but rather as reactive entities reflecting popular will. Therefore, advocates using this strategy focus on building coalitions and mobilizing the public around its causes. Furthermore, by increasing public participation in policy advocacy, these advocates believe they are enhancing democratic policy making processes themselves, in addition to affecting specific policy changes. The strategy also invokes the advocacy coalition framework (Sabatier, 1988) in two ways. First, it views coalitions as central actors in policy making, so it devotes significant efforts to coalition building. Second, it recognizes the role of learning in the policy process, so information dissemination and media work constitute an integral tactic in this strategy.

Advocates employing the institutional partnership strategy view their participation in governance as an integral part of producing effective and responsive public policies and services. Legislature and agencies left on their own may be well-intentioned but lack the public’s perspectives to optimize outcomes. Therefore, these advocates seek partnerships with government institutions do set policies and improve services. Their viewpoint aligns closely with the public participation literature in both policy making (Bryson \& Anderson, 2000; Smith \& Huntsman, 1997) and public services (Roberts, 2008). However, while these literatures espouse public participation for both normative (e.g., enhanced democracy) and descriptive (e.g., better outcomes) reasons, the advocates in our data focused on the latter. Their objectives were 
limited to reforms of specific policies and services, rather than broader democratic processes. This viewpoint also overlaps with the coproduction concept found in the public administration literature (Brudney \& England, 1983), in which service beneficiaries participate in the delivery of public services. However, in our data some of the advocates employing this strategy were not direct beneficiaries of the services they sought.

Finally, in the indirect pressure strategy, advocates target the decisions of government actors, reflecting an institutional view of policy change (Selznick, 1996). However, they choose to influence them indirectly by raising concerns about issues among the public. Thus, their preferred tactics align with the Walker's “outside” approach (1991), such as public education efforts, working with coalitions, and conducting public mobilizations. Mosely (2011) observed that organizations often favor indirect strategies when they appear to lack skill, experience or knowledge to use insider tactics such as lobbying, or find the lack of legal clarity around permissible levels of lobbying to be confusing. In our data, however, advocates preferred outside tactics as a means of establishing long-term public support to span many short-term tenures of elected officials. From a tactical perspective, the indirect pressure strategy looks a lot like the popular power strategy, in that they both mobilize the public and engage the media. However, their viewpoints are clearly distinct. Thus, their theoretical affinities are too. Indirect pressure strategists' purpose in engaging the public is to affect the decisions of government decision makers, recognizing that centrality of power in policy making. On the other hand, popular power strategists engage the public because that is where policy making power primarily resides. The two strategies may look alike in operation, but this difference in viewpoint could result in different performance metrics. 
There are a few limitations of these findings that must be accounted. First, this study only examines the strategies employed by nonprofit organizations. It makes no claims on for-profit organizations, which are also heavily engaged in policy advocacy and might reasonably be expected to use different tactics and strategies. Indeed, in this study's example of a nonprofit fighting for stricter standards on power generation, they faced stiff opposition from the coal industry which was reported to utilize money in key tactics to defend their permits (e.g., purchase media, lobby). Instead, this study focuses on the specific gap in understanding how nonprofits advocate for policy change.

The second limitation is the range of the sample across issues areas and political ideologies. The original sampling frame was constructed to carefully include organizations working in a broader range of issues areas, including those usually associated with either liberal or conservative ideologies. However, those that agreed to participate were more liberal leaning in their policy stances, and they tended to cluster around a few issue areas. For example, table 2 shows three organizations working in education, and another two in child welfare. While one of these organizations identifies itself with a conservative perspective, three are more clearly on the liberal side of the spectrum. Similarly, multiple gun rights and marriage defense organizations consistently declined aggressive recruitment to participate in this study, while those advocating for gun controls and marriage equality did participate. Thus, if politically conservative nonprofits, or those in issue areas not represented in this sample, advocate in substantively different ways, then their strategies would not be included in this study's findings. Still, the six resulting strategies reported here do collectively cover all of the categories of tactics identified in the professional and academic literatures, so any missing strategies would likely be a different combination of tactics, rather than something completely different. 
Despite these limitations, this study significantly advances our understanding of policy advocacy by nonprofit organizations. Research comparing different strategies of policy advocacy had so far largely escaped empirical analysis. This study begins to fill that gap by identifying six distinct strategies that cumulatively explain $61 \%$ of the variance the dataset. Furthermore, at least five organization loaded onto each of the six factors, suggesting highly reliable results that can be extrapolated to the study population (Brown, 1980, p. 67). For nonprofit organizations faced with the quandary of how best to plan policy advocacy efforts, this study's findings offers guidance. The strategies identified in this paper have both theoretical backing and empirical evidence of real-world usage. For the academic community, this study begins to bridge the gap between the literatures on policy advocacy organizations and policy theories, by describing advocates’ viewpoints on policy processes and linking them to existing theories.

Future research could provide greater clarity around how policy advocacy organizations make strategic decisions about activities and feasible outcomes, based on factors such as resources, membership, and geographic location. Building on the findings of this paper, we have begun research to explore the use of different tactics and strategies for organizations with different profiles. This next follow-up study involves collection of survey data with a random sample of nonprofit organizations engaged in policy advocacy across the United States.

While these strategies may be indicative of the types of approaches organizations may take, their ultimate success in creating social change will depend on social and political context. As Teles \& Schmitt (2011) point out, “...tactics that may have worked in one instance are not necessarily more likely to succeed in another. What matters is whether advocates can choose the tactic appropriate to a particular conflict and adapt to the shifting moves of the opposition” (p. 
40). Yet no general would go into battle without studying the successful strategies used in past conflicts, so knowing what organizations do to affect change can have great practical significance and can add to our emerging understanding of advocacy practice and evaluation.

\section{References}

Agranoff, Robert, and Michael McGuire. 2003. “Inside the Matrix: Integrating the Paradigms of Intergovernmental and Network Management.” International Journal of Public Administration, 26(12): 1401-1422.

Almog-Bar, Michal, and Hillel Schmid. 2013. "Advocacy Activities of Nonprofit Human Service Organizations: A Critical Review." Nonprofit and Voluntary Sector Quarterly, 43(1): 11-35.

Baumgartner, Frank R., Jeffrey M. Berry, Marie Hojnacki, David C. Kimball, and Beth L. Leech. 2009. Advocacy and Policy Change. Chicago: University of Chicago Press.

Baumgartner, Frank R., and Beth L. Leech. 1998. Basic Interests: The Importance of Groups in Politics and in Political Science. Princeton, NJ: Princeton University Press.

Berry, Jeffrey M. 1977. Lobbying for the People. The Political Behavior of Public Interest Groups. Princeton, NJ: Princeton University Press.

Berry, Jeffrey M. 1999. "The Rise of Citizen Groups." In Civic Engagement in American Democracy, ed. Theda Skocpol and Morris P. Fiorina. Washington, D.C.: Brookings Institute, 367-394.

Berry, Jeffrey M. with David F. Arons. 2003. A Voice for Nonprofits. Washington, D.C.: Brookings Institute Press.

Brown, Steven R. 1980. Political Subjectivity: Applications of Q Methodology in Political Science. New Haven, CT: Yale University Press. 
Brown, Steven R., Dan W. Durning, and Sally Selden. 1999. “Q Methodology.” In Handbook of Research Methods in Public Administration, ed. G.J. Miller and M.L. Whicker. New York: Marcel Dekker, 599-635.

Brudney, Jeffrey L., and Robert E. England. 1983. “Toward a Definition of the Coproduction Concept.” Public Administration Review, 43(1): 59-65.

Bryson, John M., and Sharon R. Anderson. 2000. “Applying Large-Group Interaction Methods in the Planning and Implementation of Major Change Efforts.” Public Administration Review, 60(2): 143-153.

Cahn, Matthew A. 1995. "The Players: Institutional and Noninstitutional Actors in the Policy Process.” In Public Policy: The Essential Readings, ed. Stella Z. Theodoulou, and Matthew A. Cahn. Englewood Cliffs, NJ: Prentice Hall, 201-211.

Casey, John. 2011. "Understanding Advocacy: A Primer on the Policy Making Role of Nonprofit Organizations." Center for Nonprofit Strategy and Management Baruch College. July. https://www.baruch.cuny.edu/spa/centers-and-institutes/center-for-nonprofit-strategy-andmanagement/documents/Casey_UnderstandingAdvocacyaPrimeronthePolicyMakingRoleofN onoprofitOrganizations.pdf (November 1, 2015).

Center for Community Health and Evaluation. N.D. "Measuring the Impact of Advocacy and Policy Efforts: Case Study Example.” http://www.civicpartnerships.org/docs/services/OLE/2010OLEConfPresentations/CCP\%20C onf_VGC\%20Eval\%20Worksheet\%20.pdf (October 15, 2012).

Chapman, Jennifer, and Amboka Wameyo. 2001. “Monitoring and Evaluating Advocacy: A Scoping Study.” Action Aid. 
http://www.actionaid.org/assets/pdf/Scoping\%20advocacy\%20paper\%202001.pdf Accessed (September 25, 2012).

Child, Curtis D., and Kirsten A. Grønbjerg. 2007. "Nonprofit Advocacy Organizations: Their Characteristics and Activities" Social Science Quarterly 88(1): 259-281.

Coffman, Julia, Astrid Hendricks, Jackie W. Kaye, Tom Kelly, and Barbara Masters. 2007. “The Advocacy and Policy Change Composite Logic Model.” Seattle, WA: Advanced Practice Institute conducted at the 8th Annual Conference of the Council on Foundations.http://www.gse.harvard.edu/hfrp/eval/issue34/index.html (September 25, 2012).

Dahl, Robert A. 1967. Pluralist Democracy in the United States: Conflict and Consent. Chicago: Rand McNally \& Company.

Edelman, Murray J. 1964. The Symbolic Uses of Politics. Champaign, IL: University of Illinois Press.

Epstein, Lee, Joseph F. Kobylka, and Joseph F. Stewart, Jr. 1995. “A Theory of Interest Groups and Litigation.” In Research in Law and Policy Studies, ed. Stuart Nagel. Greenwich, CT: JAI Press, 113-138.

Gallagher, Deborah Rigling, and Sarah E. Jackson. 2008. "Promoting Community Involvement at Brownfields Sites in Socio-Economically Disadvantaged Neighborhoods.” Journal of Environmental Planning \& Management, 51(5): 615-630.

Ganz, Marshall. 2009. Why Goliath Sometimes Wins. New York: Oxford University Press.

Gen, Sheldon, and Wright, Amy Conley. 2013. "Policy Advocacy Organizations: A Framework Linking Theory and Practice.” Journal of Policy Practice, 12(3):163-193. 
Grantmakers In Health. 2005. “Funding Health Advocacy” Washington, D.C.: GIH Issue Brief No. 21. http://www.gih.org/usr_doc/issuebrief21_Funding_Advocacy.pdf (October 18, 2012).

Herman, Edward, and Noam Chomsky. 2002. Manufacturing Consent: The Political Economy of the Mass Media. New York: Pantheon.

Hill, Michael, and Peter Hupe. 2011. Implementing Public Policy. $2^{\text {nd }}$ edition. London: Sage.

Hird, John A. 2005. Power, Knowledge, and Politics: Policy Analysis in the States. Washington, DC: Georgetown University Press

Hoefer, Richard. 2003. "Making a Difference: Human Service Interest Group Influence on Social Welfare Program Regulations." Journal of Sociology \& Social Welfare 27(3): 21-38.

Hoefer, Richard. 2001. "Highly Effective Human Services Interest Groups: Seven Key Practices." Journal of Community Practice 9(2): 1-13.

Hoefer, Richard. 2005. "Altering State Policy: Interest Group Effectiveness Among State-level Advocacy Groups." Social Work 50(3): 219-227.

Hoefer, Richard, and Kristin Ferguson. 2007. "Controlling the Levers of Power: How Advocacy Organizations Affect the Regulation Writing Process." Journal of Sociology \& Social Welfare 34 (1): 83-108.

Hopkins, Bruce R. 1992. Charity, Advocacy and the Law. New York: Wiley. Iyengar, Shanto, and Donald Kinder. 1987. News That Matters. Chicago: University of Chicago Press.

Jones, Michael D., and Mark K. McBeth. 2010. “A Narrative Policy Framework: Clear Enough to be Wrong?” Policy Studies Journal, 38(2): 329-353. 
Kagan, Robert A. 1991. “Adversarial Legalism and American Government.” Journal of Policy Analysis and Management 10(3): 369-406.

Kagan, Robert A. 1998-9. “Adversarial Legalism: Tamed or Still Wild?” New York University Journal of Legislation and Public Policy, 2(2): 217-245.

Kastens, Britta, and Jens Newig. 2008. “Will Participation Foster the Successful Implementation of the Water Framework Directive? The Case of Agricultural Groundwater Protection in Northwest Germany.” Local Environment, 13(1): 27-41.

Kingdon, John W. 1984. Agendas, Alternatives and Public Policies. New York: Longman.

Kirst-Ashman, Karen K., and Grafton H. Hull. 2008. Brooks/Cole Empowerment Series: Generalist Practice with Organizations and Communities. Belmont, CA: Brooks/Cole Cengage Learning.

Leech, Beth L., Frank R. Baumgartner, Jeffrey M. Berry, Marie Hojnacki, and David C. Kimball. 2007. “Does Money Buy Power? Interest Group Resources and Policy Outcomes.” Presented at the annual meeting of the Midwest Political Science Association, Chicago, Illinois. http://ase.tufts.edu/polsci/faculty/berry/moneyBuyPower.pdf (December 10, 2015).

Lindblom, Charles. 1959. “The Science of Muddling Through.” Public Administration Review, 19(Spring): 79-88.

Lindblom, Charles E, and David K. Cohen. 1979. Usable Knowledge: Social Science and Social Problem Solving. New Haven: Yale University Press.

Linsky, Martin. 1988. Impact: How the Press Affects Federal Policy Making. New York: W. W. Norton \& Company.

Majone, Giandomenico. 1989. Evidence, Argument and Persuasion in the Policy Process. New Haven: Yale University Press. 
McCarthy, John D., and Mayer N. Zald. 2006. "Resource Mobilization Theory: Vigorous or Outmoded?” In Handbook of Sociological Theory. ed. Jonathan H. Turner. New York: Springer Science \& Business Media.

McKeown, Bruce \& Dan Thomas. 1988. Q Methodology. Sage University Paper series on Quantitative Applications in the Social Sciences, series number 07-066. Beverly Hills: Sage Publications.

Mellinger, Marcela Sarmiento, and Stacey Kolomer. 2013. "Legislative Advocacy and Human Service Nonprofits: What Are We Doing?" Journal of Policy Practice 12(2): 87-106.

Mills, C. Wright. 1956. The Power Elite. New York: Oxford University Press.

Morariu, Johanna, Ehren Reed, Kathy Brennan, Andy Stamp, Simone Parrish, Veena Pankaj, and Lily Zandniapour, 2009. "Pathfinder Evaluation Edition: A Practical Guide to Advocacy Evaluation. Innovation Network, Inc. http://www.innonet.org/index.php?section_id=3\&content_id=601 (October 15, 2012).

Mosley, Jennifer E. 2009. "Institutionalization, Privatization, and political opportunity: What Tactical Choices Reveal about the Policy Advocacy of Human Service Nonprofits." Nonprofit and Voluntary Sector Quarterly, 40(3): 435-457.

Mosley, Jennifer E. 2010. "Organizational Resources and Environmental Incentives: Understanding the Policy Advocacy Involvement of Human Service Nonprofits." Social Service Review 84(1): 57-76.

Mosley, Jennifer. 2013. "Recognizing New Opportunities: Reconceptualizing Policy Advocacy in Everyday Organizational Practice." Social Work 58(3): 231-239.

Nachmias, David. 1980. “The Role of Evaluation in Public Policy.” Policy Studies Journal, 8(7): 1163-1169. 
Nowlin, Matthew C. 2011. “Theories of the Policy Process: State of the Research and Emerging Trends.” Policy Studies Journal, 39(S1): 41-60.

Olson, Mancur. 1965. The Logic of Collective Action: Public Goods and the Theory of Groups. Cambridge, MA: Harvard University Press.

Putnam, Robert D. 1976. The Comparative Study of Political Elites. Upper Saddle River, NJ: Prentice Hall.

Reisman, Jane, Anne Gienapp, and Sarah Stachowiak. 2007. “A Guide to Measuring Advocacy and Policy.” Prepared by Organizational Research Services for Annie E. Casey Foundation. http://www.aecf.org/resources/a-guide-to-measuring-advocacy-and-policy/ (October 2, 2012).

Ripley, Randall B., and Grace A. Franklin. 1984. Congress, the Bureaucracy, and Public Policy. Belmont, CA: Dorsey Press.

Roberts, Nancy C. (ed.). 2008. The Age of Direct Citizen Participation. Armonk, NY: M.E. Sharpe.

Sabatier, Paul A. 1988. “An Advocacy Coalition Framework of Policy Change and the Role of Policy-oriented Learning Therein.” Policy Sciences, 21(2-3): 129-168.

Schmid, Hillel, Michal Bar, and Ronit Nirel. 2008. "Advocacy Activities in Nonprofit Human Service Organizations Implications for Policy." Nonprofit and Voluntary Sector Quarterly 37(4): 581-602.

Schneider, Anne L. and Helen M. Ingram. 1993. "Social Construction of Target Populations: Implications for Politics and Policy.” The American Political Science Review, 87(2): 334347. 
Selznick, Philip. 1996. “Institutionalism ‘Old' and 'New'.” Administrative Science Quarterly, 41(2): 270-277.

Simon, Herbert. 1945. Administrative Behavior: A Study of Decision Making Processes in Administrative Organizations. Mankato, MN: The Free Press.

Smith, Gerald E., and Carole A. Huntsman. 1997. "Reframing the Metaphor of CitizenGovernment Relationship: A Value-Centered Perspective.” Public Administration Review, 57(4): 309-318.

Teles, Steven, and Mark Schmitt. 2011. "The Elusive Craft of Evaluating Advocacy.” Stanford Social Innovation.

http://www.ssireview.org/images/digital_edition/2011SU_Feature_TelesSchmitt.pdf (October 21, 2014).

Walker, Jack L. 1983. "The Origins and Maintenance of Interest Groups in America." American Political Science Review, 77(2): 390-406.

Walker, Jack L. 1991. Mobilizing Interest Groups in America: Patrons, Professions, and Social Movements. Ann Arbor, MI: University of Michigan Press.

Wasby, S. L. 1983. “Interest Groups and Litigation”. Policy Studies Journal, 11(4), 657-670.

Watts, Simon, and Paul Stenner. 2005. “Doing Q Methodology: Theory, Method and Interpretation.” Qualitative Research in Psychology, 2: 67-91.

Watts, Simon, and Paul Stenner. 2012. Doing Q Methodological Research: Theory, Method \& Interpretation. Thousand Oaks, CA: Sage Publications.

Weiss, Carol H., and Michael J. Bucuvalas. 1980. “Truth Tests and Utility Tests: DecisionMakers’ Frames of Reference for Social Science Research.” American Sociological Review, 45(2): 302-313. 
Xu, Jun. 2005. "Why Do Minorities Participate Less? The Effects of Immigration, Education, and Electoral Process on Asian American Voter Registration and Turnout.” Social Science Research, 34(4): 682-702. 
Table 1: Advocacy activities and their theoretical linkages to outcomes

\begin{tabular}{|c|c|c|}
\hline Activities & Theoretical link & Outcomes and impacts \\
\hline $\begin{array}{l}\text { Coalition building; } \\
\text { Engaging and mobilizing the } \\
\text { public; Information } \\
\text { campaigning }\end{array}$ & $\begin{array}{l}\text { Advocacy coalition } \\
\text { framework (Sabatier, } \\
\text { 1988); Interest group studies } \\
\text { (Baumgartner \& Leech, 1998) }\end{array}$ & $\begin{array}{l}\text { Changes in public views; } \\
\text { Changes in decision makers' } \\
\text { views; Policy adoption }\end{array}$ \\
\hline Engaging decision makers & $\begin{array}{l}\text { Institutionalism (Cahn, 1995) } \\
\text { Elite theory (Mills, 1956; } \\
\text { Putnam, 1976) }\end{array}$ & $\begin{array}{l}\text { Changes in decision makers' } \\
\text { views; Policy adoption }\end{array}$ \\
\hline $\begin{array}{l}\text { Information campaigning: } \\
\text { research and analysis }\end{array}$ & $\begin{array}{l}\text { Rational decision making } \\
\text { (Lindblom \& Cohen, 1979; } \\
\text { Weiss \& Bucuvalas, 1980) }\end{array}$ & $\begin{array}{l}\text { Changes in public views; } \\
\text { Changes in decision makers' } \\
\text { views; Policy adoption }\end{array}$ \\
\hline $\begin{array}{l}\text { Information campaigning: } \\
\text { rhetoric (e.g., issue framing, } \\
\text { labeling, anecdotes, etc.) }\end{array}$ & $\begin{array}{l}\text { Rhetoric studies (Schneider } \\
\text { and Ingram, 1993; Nowlin, } \\
\text { 2011; Jones \& McBeth, 2010) }\end{array}$ & $\begin{array}{l}\text { Changes in public views; } \\
\text { Changes in decision makers' } \\
\text { views; Policy adoption }\end{array}$ \\
\hline $\begin{array}{l}\text { Information campaigning: } \\
\text { media work }\end{array}$ & $\begin{array}{l}\text { Media studies (Nowlin, 2011; } \\
\text { Iyengar and Kinder, 1987; } \\
\text { Linsky, 1988) }\end{array}$ & $\begin{array}{l}\text { Changes in public views; } \\
\text { Changes in decision makers' } \\
\text { views; Sets policy agenda; } \\
\text { Raises political will to act; } \\
\text { Hastens action }\end{array}$ \\
\hline Reform efforts: litigation & $\begin{array}{l}\text { Adversarial legalism (Kagan } \\
\text { 1991, 1999) }\end{array}$ & Policy adoption \\
\hline $\begin{array}{l}\text { Reform efforts: pilots, } \\
\text { demonstrations }\end{array}$ & $\begin{array}{l}\text { Incrementalism (Lindblom, } \\
\text { 1959) }\end{array}$ & $\begin{array}{l}\text { Changes in public views; } \\
\text { Changes in decision makers' } \\
\text { views; Policy adoption }\end{array}$ \\
\hline Defensive activities & $\begin{array}{l}\text { Public dialectic (Majone, } \\
\text { 1989); Policy-oriented } \\
\text { learning (Sabatier, 1988) }\end{array}$ & $\begin{array}{l}\text { Changes in public views; } \\
\text { Changes in decision makers' } \\
\text { views }\end{array}$ \\
\hline Policy monitoring & $\begin{array}{l}\text { Bottom-up implementation } \\
\text { theories (Hill \& Hupe, 2011) }\end{array}$ & $\begin{array}{l}\text { Changes in bureaucrats' } \\
\text { actions }\end{array}$ \\
\hline Policy monitoring & $\begin{array}{l}\text { Evaluation theory (Nachmias, } \\
\text { 1980) }\end{array}$ & Setting the policy agenda \\
\hline $\begin{array}{l}\text { Information campaigning; } \\
\text { Engaging, mobilizing public; } \\
\text { Engaging decision makers }\end{array}$ & $\begin{array}{l}\text { Multiple streams theory } \\
\text { (Kingdon, 1984) }\end{array}$ & $\begin{array}{l}\text { Setting the policy agenda; } \\
\text { Policy adoption }\end{array}$ \\
\hline $\begin{array}{l}\text { Engaging and mobilizing the } \\
\text { public }\end{array}$ & $\begin{array}{l}\text { Public participation (Bryson } \\
\text { \& Anderson, 2000; Kastens \& } \\
\text { Newig, 2008; Xu, 2001; } \\
\text { Kastens \& Newig, 2008; } \\
\text { Gallagher \& Jackson, 2008) }\end{array}$ & $\begin{array}{l}\text { Democratic environment; } \\
\text { People-centered policy } \\
\text { making }\end{array}$ \\
\hline
\end{tabular}


Table 2: Participating policy advocacy nonprofits

\begin{tabular}{rllr}
\hline $\begin{array}{r}\text { Organization } \\
\text { number }\end{array}$ & $\begin{array}{l}\text { Levels of government } \\
\text { case }\end{array}$ & $\begin{array}{l}\text { Policy issue area of } \\
\text { advocacy case }\end{array}$ & $\begin{array}{r}\text { Program expenses } \\
\text { reported in Guidestar } \\
\text { (year) }\end{array}$ \\
\hline 1 & national, state, local & environment & $\$ 133,418(2009)$ \\
2 & national & public health & $\$ 13,267(2007)$ \\
3 & state, local & residential care & $\$ 829,359(2010)$ \\
4 & local & child welfare & $\$ 1,147,295(2012)$ \\
5 & local & senior welfare & $\$ 304,979(2012)$ \\
6 & national, state & criminal justice & $\$ 361,882(2009)$ \\
7 & national, local & sustainability & $\$ 224,064(2006)$ \\
8 & local & land conservation & $\$ 1,955,370(2010)$ \\
9 & local & social equity & not available \\
10 & national, state, local & civic engagement & $\$ 1,130,853(2011)$ \\
11 & national, local & disabilities & $\$ 292,235(2010)$ \\
12 & local & parks & $\$ 233,686(2009)$ \\
13 & state, local & arts & not available \\
14 & national, state, local & land conservation & $\$ 119,592,234(2012)$ \\
15 & state & energy, telecom & $\$ 3,497,658(2010)$ \\
16 & state, local & juvenile justice & $\$ 1,397,100(2009)$ \\
17 & local & pedestrian & $\$ 60,163(2011)$ \\
18 & national, local & war, gun violence & $\$ 378,475(2012)$ \\
19 & national, state & child welfare & $\$ 3,749,406(2012)$ \\
20 & national, state, local & environment & $\$ 56,641,344(2012)$ \\
21 & national, state, local & public health & $\$ 11,412,991$ (2013) \\
22 & State & education & not available \\
23 & state, local & education & not available \\
24 & local & education & $\$ 474,429(2013)$ \\
25 & national, state & peace and justice & $\$ 31,211,428(2011)$ \\
26 & national, state & criminal justice & $\$ 2,155,658(2012)$ \\
27 & state, local & civil rights & $\$ 1,636,906(2013)$ \\
28 & State & foster youth & $\$ 1,096,788(2010)$ \\
29 & local & environment & $\$ 3,390,216(2012)$ \\
30 & national, state & civil rights & $\$ 5,594,924(2011)$ \\
31 & national, state & environment & $\$ 2,539,617(2012)$ \\
\hline & & & \\
\hline
\end{tabular}


Table 3: Factor loadings matrix with defining sorts

\begin{tabular}{|c|c|c|c|c|c|c|}
\hline $\begin{array}{c}\text { Org. } \\
\text { number }\end{array}$ & factor 1 & factor 2 & factor 3 & factor 4 & factor 5 & factor 6 \\
\hline 1 & 0.1618 & 0.0313 & 0.0538 & 0.3078 & $0.4323 *$ & $0.5327 * *$ \\
\hline 2 & -0.0740 & 0.3882 & $0.5807 * *$ & 0.0012 & 0.0056 & 0.1712 \\
\hline 3 & -0.2266 & -0.2023 & $-0.6820^{* *}$ & -0.2344 & -0.0002 & -0.2831 \\
\hline 4 & $0.4558 *$ & 0.2034 & 0.2061 & 0.1846 & 0.1989 & 0.2759 \\
\hline 5 & 0.2818 & $-0.4423 *$ & -0.1680 & 0.1861 & $0.4588 *$ & 0.0688 \\
\hline 6 & 0.1584 & 0.0578 & $0.5176^{*}$ & 0.3411 & 0.0621 & -0.2180 \\
\hline 7 & -0.0647 & 0.1620 & 0.0400 & $-0.5820 * *$ & -0.2605 & $-0.4200 *$ \\
\hline 8 & $0.7361 * *$ & 0.0736 & 0.1988 & -0.3266 & 0.1596 & 0.0607 \\
\hline 9 & -0.0473 & $-0.6564 * *$ & $0.4689 *$ & -0.0862 & 0.1020 & -0.2077 \\
\hline 10 & -0.0597 & -0.0450 & 0.3397 & $0.6769 * *$ & 0.2956 & 0.2758 \\
\hline 11 & -0.0781 & 0.0424 & -0.0792 & -0.0068 & 0.0807 & $-0.4905^{*}$ \\
\hline 12 & -0.0420 & 0.3704 & 0.1135 & 0.1918 & 0.1901 & $0.5609 * *$ \\
\hline 13 & $0.7104 * *$ & 0.0223 & -0.1457 & 0.1434 & -0.1060 & -0.1752 \\
\hline 14 & $0.7634 * *$ & 0.1933 & 0.1751 & 0.0713 & 0.1980 & 0.1705 \\
\hline 15 & $0.4491 *$ & 0.2942 & -0.0403 & 0.3808 & 0.3695 & -0.0504 \\
\hline 16 & 0.1031 & 0.1424 & $0.5070 *$ & -0.0626 & 0.3280 & $0.5966^{* *}$ \\
\hline 17 & 0.2873 & $0.6721^{* *}$ & 0.0980 & 0.1532 & $0.5496 * *$ & 0.1201 \\
\hline 18 & 0.0662 & 0.0496 & -0.1202 & $0.8240 * *$ & -0.0390 & -0.1154 \\
\hline 19 & 0.2319 & $0.6898 * *$ & -0.0260 & -0.1609 & 0.2721 & 0.2877 \\
\hline 20 & 0.1579 & 0.1571 & 0.3026 & $0.7163^{* *}$ & -0.1715 & 0.3635 \\
\hline 21 & 0.0208 & $0.6727 * *$ & 0.0715 & 0.0545 & -0.0956 & -0.0650 \\
\hline 22 & 0.0704 & $0.5579 * *$ & 0.2832 & 0.2864 & -0.1431 & 0.3695 \\
\hline 23 & 0.2940 & 0.2173 & -0.1153 & -0.1822 & $0.5971^{* *}$ & 0.0596 \\
\hline 24 & 0.3200 & 0.1951 & -0.0794 & $0.4048 *$ & 0.0902 & 0.0722 \\
\hline 25 & -0.0757 & -0.0354 & 0.0316 & 0.0907 & $0.8151^{* *}$ & 0.0051 \\
\hline 26 & $0.5693 * *$ & 0.0558 & 0.1160 & 0.2750 & 0.1823 & 0.3975 \\
\hline 27 & -0.0343 & 0.0476 & $0.7948 * *$ & -0.2690 & -0.1494 & 0.1674 \\
\hline 28 & 0.3396 & -0.1123 & 0.3728 & 0.1947 & $0.4520 *$ & 0.1754 \\
\hline 29 & 0.1419 & $0.7343 * *$ & 0.2869 & 0.0711 & 0.1277 & -0.1767 \\
\hline 30 & -0.0304 & -0.2738 & 0.3953 & 0.1088 & -0.0065 & 0.2494 \\
\hline 31 & $-0.5206^{*}$ & 0.2954 & $0.4104^{*}$ & -0.1845 & 0.1093 & -0.0952 \\
\hline $\begin{array}{c}\text { explained } \\
\text { variance } \\
(61 \% \\
\text { total) }\end{array}$ & $11 \%$ & $12 \%$ & $11 \%$ & $10 \%$ & $9 \%$ & $8 \%$ \\
\hline
\end{tabular}


Table 4: Extracted factor arrays for 24 policy advocacy statements

\begin{tabular}{|c|c|c|c|c|c|c|c|}
\hline \multirow[t]{2}{*}{ No. } & \multirow[t]{2}{*}{ Statement } & \multicolumn{6}{|c|}{ Factor Arrays } \\
\hline & & 1 & 2 & 3 & 4 & 5 & \\
\hline 1 & $\begin{array}{l}\text { Developing messages, framing issues, labeling and other } \\
\text { strategies of rhetoric can change policy makers' views. }\end{array}$ & 1 & 3 & F & 0 & 2 & -1 \\
\hline 2 & $\begin{array}{l}\text { Lobbying and building relationships with policy makers can } \\
\text { change their views. }\end{array}$ & 3 & 2 & 0 & 0 & 2 & 1 \\
\hline 3 & $\begin{array}{l}\text { Monitoring and evaluating existing policy can change how it } \\
\text { is implemented. }\end{array}$ & -2 & -1 & 1 & -1 & 1 & 1 \\
\hline 4 & $\begin{array}{l}\text { Building coalitions and networks with like-minded } \\
\text { organizations and individuals can change the public's views. }\end{array}$ & -1 & 0 & 0 & 3 & 1 & -1 \\
\hline 5 & Rebutting op & -2 & 1 & 0 & -2 & -3 & -2 \\
\hline 6 & $\begin{array}{l}\text { Using } \\
\text { policy }\end{array}$ & 1 & 3 & $\mathrm{C}^{-}$ & 1 & 0 & \\
\hline 7 & $\begin{array}{l}\text { Monitoring a } \\
\text { agenda. }\end{array}$ & -1 & -1 & 1 & -2 & -1 & 0 \\
\hline 8 & 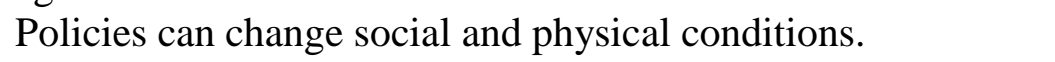 & J & 1 & 3 & 2 & -2 & \\
\hline 9 & ion can change the & -1 & 0 & & 3 & 1 & \\
\hline 10 & $\begin{array}{l}\text { ons and networks with like-minded } \\
\text { Id individuals can change policy makers’ }\end{array}$ & 0 & 2 & -2 & 1 & 3 & 0 \\
\hline 11 & d & 2 & -3 & -1 & 0 & -2 & -2 \\
\hline 12 & Policy & 0 & -2 & -3 & -1 & -1 & -3 \\
\hline 13 & grams and demonstration projects can lead to $\mathrm{p}$ & -1 & -2 & -1 & -2 & 2 & 2 \\
\hline 14 & nobilizations (e.g., protests, letter writing campaigns, & -2 & 0 & -3 & 1 & -1 & \\
\hline 15 & & . & 1 & -1 & -3 & 3 & 0 \\
\hline 16 & Usin & 1 & 2 & 2 & 0 & 0 & \\
\hline 17 & - & -3 & -3 & 3 & -1 & -2 & -1 \\
\hline 18 & & -3 & -1 & -2 & 0 & -3 & -2 \\
\hline 19 & Changes in the public's views can ch & 0 & 0 & 1 & 0 & 0 & \\
\hline 20 & Developing messages, framing issues, labelin & 0 & 1 & 2 & 2 & 0 & \\
\hline 21 & $\begin{array}{l}\text { Public mobilizations (e.g., protests, letter writing campaigns } \\
\text { voter registration) can build democracy. }\end{array}$ & 0 & -2 & -2 & 2 & 0 & \\
\hline 22 & .. & 2 & 0 & 0 & 1 & 1 & 2 \\
\hline 23 & - & 0 & 0 & -1 & -3 & 0 & \\
\hline 24 & Policy advocacy in general produces more effective policies & 2 & -1 & 0 & -1 & -1 & - -2 \\
\hline
\end{tabular}

Variance $=2.833$, St. Dev. $=1.683$ 
Table 5: Policy advocacy strategies and their affinities to policy theories

\begin{tabular}{|c|c|c|}
\hline $\begin{array}{l}\text { Factor: } \\
\text { Strategy }\end{array}$ & Key tenets & Theoretical affinities and extrapolations \\
\hline $\begin{array}{l}\text { 1: Public } \\
\text { lobbying }\end{array}$ & $\begin{array}{l}\text { - Viewpoint: advocates see themselves as interpreters } \\
\text { and champions of public interest } \\
\text { - Tactics: build relationships with policy makers and } \\
\text { lobby them, provide political cover } \\
\text { - Expected outcomes: changes in policy and } \\
\text { social/physical conditions, people-centered policies }\end{array}$ & $\begin{array}{l}\text { - Institutionalism (Selznick, 1996): advocates focus on } \\
\text { the decision making autonomy of legislatures and } \\
\text { bureaucracies, and the formal processes of policy } \\
\text { making } \\
\text { - Baumgartner et al.’s (2009) lobbying, and Walker's } \\
\text { (1991) inside strategy: advocates rely on direct } \\
\text { relationships with decision makers to influence them }\end{array}$ \\
\hline $\begin{array}{l}\text { 2: Inside/ } \\
\text { outside }\end{array}$ & $\begin{array}{l}\text { - Viewpoint: policy change requires a champion inside } \\
\text { the decision making body, combined with public } \\
\text { pressure } \\
\text { - Tactics: lobby and nurture a champion inside the } \\
\text { decision making body, information dissemination to } \\
\text { build public support } \\
\text { - Expected outcomes: policy change }\end{array}$ & $\begin{array}{l}\text { - Walker's (1991) inside and outside strategies } \\
\text { - Kingdon's (1984) streams theory: advocates advance } \\
\text { the problem, policy, and politics streams while } \\
\text { supporting a policy entrepreneur on the inside }\end{array}$ \\
\hline $\begin{array}{l}\text { 3: Direct } \\
\text { reform }\end{array}$ & $\begin{array}{l}\text { - Viewpoint: advocates represent specific interests by } \\
\text { bypassing legislative processes and focusing on } \\
\text { judicial and administrative processes } \\
\text { - Tactics: litigation, monitoring; combined with } \\
\text { information campaigns to build public support } \\
\text { - Expected outcome: policy change, changes in } \\
\text { physical/social conditions }\end{array}$ & $\begin{array}{l}\text { - Adversarial legalism (Kagan, 1991, 1999): Advocates } \\
\text { use the courts to advance their arguments and engage } \\
\text { in political bargaining to reach compromises } \\
\text { - Incrementalism (Lindblom, 1959): low-risk } \\
\text { demonstration can lead to systemic change } \\
\text { - Media work (Linsky, 1988): advocates use media to } \\
\text { raise public awareness and increase political pressure }\end{array}$ \\
\hline $\begin{array}{l}\text { 4: Popular } \\
\text { power }\end{array}$ & $\begin{array}{l}\text { - Viewpoint: a mobilized public can change policies } \\
\text { and conditions, and enhance democracy } \\
\text { - Tactics: building coalitions, public mobilization, } \\
\text { media work } \\
\text { - Expected outcomes: policy change, responsive } \\
\text { policies, enhanced democracy }\end{array}$ & $\begin{array}{l}\text { - Walker's (1991) outside strategy: advocates build } \\
\text { popular support for their cause, expecting policy } \\
\text { change to follow } \\
\text { - Resource mobilization theory (McCarthy \& Zald, } \\
\text { 2006): advocates engage in mobilization efforts and } \\
\text { media work to attempt to gain adherents to their cause. } \\
\text { - Advocacy coalition framework (Sabatier, 1988): }\end{array}$ \\
\hline
\end{tabular}


5: Institutional partnership

6: Indirect pressure
- Viewpoint: advocates are partners with government institutions to reform policies

- Tactics: coalition building, research, messaging, lobbying

- Expected outcomes: policy change

- Viewpoint: policy makers' views are swayed by public's, so advocates mobilize the public

- Tactics: public mobilization, media work, pilot programs

- Expected outcomes: changes in policy makers' views, and policy change coalitions and learning among the policy community are central to policy change

- Public participation: advocates partner with government to produce more democratic and effective policies (Bryson \& Anderson, 2000; Smith \&

Huntsman, 1997) and public services (Roberts, 2008).

- Institutionalism (Selznick, 1996) and indirect/outside tactics (Walker, 1991): advocates focus on the policy makers' power to change policy, but influence them indirectly through public pressure. 